\title{
A legislação canônica da escolha dos bispos no primeiro milênio
}

\author{
The Canonical Legislation of the Selection of Bishops \\ in the First Century
}

Reginaldo Roberto Luiz ${ }^{1}$

Resumo: Um dos temas de maior importância na história da Igreja, sem dúvida é a designatio episcoporum, isto é, a escolha dos bispos. Durante o primeiro milênio, é possível encontrar inúmeras fontes que abordam as diversas eclesiologias, formas e sistemas das escolhas episcopais. Desde o contexto do Novo Testamento, passando pelos séculos seguintes, seja em âmbito consuetudinário ou legislativo, dentro e fora da Igreja, nos mostra que a escolha do bispo, era um tema primordial na Igreja e na sociedade. Essa problemática, seja abordada no âmbito dos concílios, dos escritores eclesiásticos, ou até mesmo por meio das determinações por parte do poder temporal, era foco de grande responsabilidade e interesse de imperadores, reis, príncipes, nobres, etc. Por parte da Igreja, houve grande preocupação em abster-se de influencias negativas por parte do poder civil e dos eclesiásticos que não respondiam a uma verdadeira evangelização,
Abstract: One of the most important themes in the history of the Church is undoubtedly the designatio episcoporum, that is, the choice of bishops. During the first millennium, it is possible to find numerous sources that address the various ecclesiologies, forms and systems of episcopal selection. From the context of the New Testament, and through the following centuries, whether by custom or legislative means, inside and outside the Church, it can be demonstrated that the choice of bishop was a primary theme in the Church and society. This problem, whether addressed within the councils, the ecclesiastical writers, or even through the determinations of temporal power, was the focus of great responsibility and interest of emperors, kings, princes, nobles, etc. On the part of the Church, there was great concern in refraining from negative influences on the part of the civil power and ecclesiastics that did not re-

1 Doutor em Utroque Iure pela Pontifícia Universidade Lateranense de Roma; Conselheiro Geral da Ordem da Bem Aventurada Virgem Maria das Mercês em Roma. Secretário Geral de Pastoral da Ordem. Postulador Geral das causas de beatificação e canonização da Ordem. Coordenador da Equipe de Textos Legislativos da Ordem. Responsável pelas Campanhas Redentoras da Ordem. Cronista da Cúria Geral. E-mail: reginaldorobertoluiz@hotmail.com 
como pode-se observar nos textos da patrologia, nas legislações conciliares, etc. Por outro lado, havia o grande interesse do poder temporal nas escolhas episcopais, que lhes garantiriam um grande $s t a-$ tus, não tendo em um primeiro momento, uma preocupação espiritual, como tal, mas simplesmente com interesses mundanos. Portanto, essa é uma história marcada por tensões, conflitos e de muita instabilidade que sempre esteve presente nas escolhas dos candidatos ao episcopado.

Palavras Chave: escolha, bispo, consenso, confirmação e poder temporal. spond to true evangelization, as can be seen in the texts of patrology, in the conciliar legislations, etc. On the other hand, there was the great interest of the temporal power in episcopal selection, which would guarantee the temporal powers great status, not having at first a spiritual concern as such, but simply with worldly interests. Therefore, this is a story marked by tensions, conflicts and great instability that has always been present in the selection of candidates for the episcopate.

Keywords: selection, bishop, consensus, confirmation and temporal Power.

\section{Introdução}

A contextualização do episcopado, em sua roupagem primeira, é proporcionada pela Sagrada Escritura, por meio do Novo Testamento, momento histórico no qual Jesus Cristo escolheu aqueles que se tornaram seus apóstolos, dando-lhes a competência de escolher seus sucessores, alicerçados no primado de Pedro: «Tu és Pedro, e sobre esta pedra edificarei a minha Igreja, e as portas do Inferno nunca prevalecerão contra ela» ${ }^{2}$. Nos limites deste trabalho, não se pretende esgotar o assunto em todas as nuanças históricas da Igreja no primeiro milênio, mas, em linhas gerais, trazer à tona a problemática e a complexidade sobre a escolha dos bispos, mostrando as variadas formas ${ }^{3}$ das designações episcopais.

Diante desse contexto histórico, aflorará o direito, ou mais propriamente, o privilégio concedido a imperadores, reis e príncipes no que concerne às nomeações episcopais. Observar-se-á que o tema das designações episcopais em suas mais variadas formas percorreu um caminho histórico-canônico permeado de períodos muito complexos e problemáticos, nos quais se verificaram muitas mudanças, com diver-

Cf. Mt 16, 18.

Cf. C. Floristán, A escolha dos bispos, in AA.Vv., Bispos para esperança do mundo: uma leitura crítica sobre caminhos de Igreja, São Paulo, 2000, 259. 
sos sistemas e eclesiologias. Embora não tenha sido formulado como $\operatorname{dogma}^{4}$ em contexto doutrinário-legislativo.

Diante disso, pretende-se, aqui, fazer uma abordagem histórica da escolha dos bispos, levando em consideração os diversos sistemas, modalidades e formas de escolha episcopal. Para tanto, serão abordados os vários períodos ${ }^{5}$ da história da Igreja, enfatizando algum momento específico e particular, alicerçado nos textos originais de importantes escritores eclesiásticos e nos concílios, que foram muito significativos para a tradição da Igreja, pois não se pode ignorar que a escolha dos bispos possui relevantíssima importância para a Igreja, já que dependerá da postura de cada um dos eleitos a continuidade evangelizadora do ensinamento cristão.

\section{Do Novo Testamento até a Didaqué}

Narra o Novo Testamento que Jesus Cristo escolheu doze apóstolos, aos quais delegou a pregação do Evangelho a toda criatura. $\mathrm{Na}$ vivência heroica da boa nova, multiplicaram-se discípulos e surgiram as comunidades ${ }^{6}$ que tinham a finalidade de partir o pão e celebrar o memorial da morte e ressurreição do Senhor. O próprio Jesus escolheu

4 Cf. J. H. Provost - K. Walf, A escolha dos bispos, in Concilium (1988), n. 220, 3.

5 Cf. Evidentemente é um grande desafio fazer uma precisa divisão dos períodos da história das escolhas episcopais. Por isso, nesse artigo, há uma proposta de divisão desses períodos que se diferem e também se assemelham à pesquisa de outros autores: Cf. J. I. GONSÁlEZ FAUS, Nenhum bispo imposto: as eleições Episcopais na história da Igreja, São Paulo, 1996; Cf. M. TKHOROVSKYY, Procedura per la nomina dei Vescovi: evoluzione dal Codice del 1917 al Codice del 1983, Roma, 2004; Cf. C. FloRistÁn, A escolha, 257-271; Cf. J. Eugi, La partecipazione della Comunità Cristiana all'elezione dei Vescovi tra il I e il V Secolo, in (D. J., ANDRÉs GuTIÉRREZ, cur.), Il processo di designazione dei Vescovi. Storia, legislazione, prassi. Atti del X Symposium Canonistico-Romanistico, Coll. Utrumque ius, 27, Città del Vaticano, 1996, 49-66; Cf. R. KotTJE, A escolha das autoridades eclesiásticas: fatos históricos e experiências, in Concilium, (1971), n. 63, 346-354; Cf. W. M. Plöchl, Storia del Diritto Canonico. Dalle origini della Chiesa allo scisma d'Oriente (1054), I, Milano, 1963.

6 Cf. R. SchnackenBURG, Participação da comunidade por consenso e eleição no Novo Testamento, in Concilium (1972), n. 77, 856. 
entre todos os discípulos somente doze ${ }^{7}$, uma simbologia com as doze tribos de Israel, que se tornaram apóstolos por vocação do Senhor e a quem foi confiada uma importante missão junto a humanidade, sedenta e necessitada de uma nova evangelização.

Com a traição de Judas abre-se uma vaga, no Colégio Apostólico e, na «votação para completar o número dos doze ${ }^{8}$, o grande grupo dos irmãos apresenta dois candidatos idôneos: deitaram a sorte e caiu a sorte em Matias (At 1, 15-26)» ${ }^{9}$. Proclamado como novo apóstolo, esse «eleito é considerado como escolhido pelo próprio Senhor, ou melhor, é o vocacionado (At 1, 15-26)» ${ }^{10}$. Esse importante acontecimento ocorrido antes de Pentecostes, foi possível graças à colaboração da comunidade primitiva de Jerusalém, seguindo a orientação dos que tinham autoridade naquele grupo de irmãos.

A escolha de Matias por meio da sorte ${ }^{11}$ representou, naquele momento histórico, um procedimento útil, na medida em que deixa transparecer que, naquele procedimento, incidia a vontade divina.

7 Cf. Mc 3, 13-19; Cf. Lc 6, 12-16; Cf. Mt 10, 1-16; Cf. Jo 1, 35-51. Esses são textos da Sagrada Escritura em que Jesus Cristo escolheu os doze apóstolos para continuar o seu projeto da construção do Reino dos Deus. Aqui fala diretamente de escolha e também da missão que lhes fora designada pelo Filho de Deus. Portanto, é Deus que escolhe e reveste de toda autoridade para o comprimento da obra de Deus.

8 Cf. At 1, 15-26. A eleição de Matias teve uma grande cooperação da comunidade cristã primitiva que contou com Pedro ao presidir a assembleia e ainda com a presença dos apóstolos. Nessa perspectiva, os estudiosos fazem referência a eleição de Matias nos Atos dos Apóstolos, chegando à conclusão que as futuras designações episcopais dizem respeito a todo o novo povo de Deus: Cf. G. CoRBELLINI, Le modalità per la scelta dei candidati all Episcopato nel Codice di Diritto Canonico con particolare riferimento alle proposte avanzate per la redazione dei nuovi canoni, in (D. J., ANDRÉs GUTIÉRREZ, cur.), II processo di designazione dei Vescovi. Storia, legislazione, prassi. Symposium CanonisticoRomanistico, Città del Vaticano, 1996, 341.

9 P. STOCKMEIER, A eleição do bispo pelo clero e pelo povo na Igreja primitiva, in Concilium (1980), n. 157, 7.

R. SCHNACKEnBURG, Participação, 857.

11 Cf. At 1, 26. Aqui é muito importante esclarecer que não se tratava simplesmente de uma sorte entendida em tempos hodiernos, mas de uma sorte que estava vinculada a um procedimento que era o suporte para ter acesso à vontade divina: $\mathrm{Cf}$. P. STOCKMEIER, $A$ eleição, 7. 
Nesse contexto, pode-se afirmar que a escolha perpassa por uma inspiração divina e, porque não dizer, sob a condução de Deus, isto é, ela estava imbuída de uma graça divina, levando em consideração o aspecto pneumático, que de maneira alguma pode ser excluída, na qual a comunidade funcionava como um órgão de escolha ${ }^{12}$.

A comunidade da Igreja Primitiva possuía uma influência muito abrangente. Encontramos em At 6, 1-7, sua atuação efetiva na escolha dos diáconos. Vê-se também aqui a nítida atuação do Espírito Santo, mantendo toda a comunidade em comunhão participativa. A escolha do chamado "círculo dos sete" ${ }^{13}$, é resultado "de uma codeterminação por consenso e eleição" ${ }^{14}$. Esses sete diáconos eram aqueles que ajudavam os apóstolos nos trabalhos pastorais naquele contexto neotestamentário. Essa escolha sem dúvida aconteceu por meio da ação divina. Com o crescimento sempre maior do número de discípulos, fezse necessário escolher cada vez mais pessoas dignas e confiáveis para auxiliar na propagação da doutrina de Cristo. Assim é que a comunidade (At 15, 22-29), na figura dos apóstolos e anciãos, escolhe os missionários que seriam enviados a Antioquia, juntamente com Paulo e Barnabé (cf. 1Tm 1, 18; 4, 14), que, por sua vez, fizeram outros missionários ${ }^{15}$. Certamente, Paulo é um grande missionário, instrumento utilizado por Deus para falar às comunidades paulinas ${ }^{16}$. Entre as muitas citações da Sagrada Escritura em que Paulo faz recomendações às comunidades, pode-se mencionar: 1 Cor 3, 5; Gal 4, 19; 2Cor 10, 8;

12 Cf. P. STOCKMEIER, A eleição, 8.

13 Cf. R. Schnackenburg, Participação, 858; Cf. A escolha dos sete diáconos, que eram colaboradores dos apóstolos, nos mostra que «questi e altri testi del Nuovo Testamento non disegnano un `immagine unitaria del modo in cui venivano costituiti i capi ecclesiastici, però accennano fortemente al fatto della partecipazione e del ruolo della comunità nell 'elezione. Tale atteggiamento è spiegabile sia a partire dalla tradizione giudaica che dal profondo senso comunitário»: Cf. M. TKHOROvSKYY, Procedura, 11.

14 R. Schnackenburg, Participação, 858.

15 Cf. Tm 1, 5. A importância desse texto bíblico nos mostra que foram instituídos missionários como presbíteros na realidade daqueles que se convertiam: $\mathrm{Cf}$. $\mathrm{P}$. STOCKMEIER, A eleição, 8.

16 Cf. 2Cor 5, 18-21. A comunicação de Paulo com a comunidade, sendo ele o mensageiro em que Deus se manifesta e fala por meio dele aos irmãos ali reunidos. 
13, 10; 1Cor 3, 1-3; F1 3, 5. Nesses textos, Paulo é mensageiro do próprio Cristo. Está cônscio de que não resolveria todas as dificuldades daquelas comunidades sozinho: «é um exemplo de que Paulo visa um real consenso entre ele e a comunidade, consenso atrás do qual está a força de Cristo»» ${ }^{17}$.

Uma ação muito curiosa de Paulo é quando ele sugere que a comunidade escolha um juiz para sanar os problemas (Co 6,5). É uma atitude de comunhão e participação da parte de Paulo, porque ele próprio não faz a nomeação, mas sugere que a comunidade faça a escolha. Em geral, no Novo Testamento, os ministros são apresentados sempre no plural ${ }^{18}$. E é impressionante observar o ambiente espiritual existente entre eles, pois procuravam, mesmo com as diferenças humanas, orientarem-se pela força de Deus.

Quando os apóstolos ficaram à frente da Igreja, no chamado período apostólico, os bispos eram escolhidos pelos próprios apóstolos ${ }^{19}$. Em seguida, os novos bispos que estavam inseridos na sucessão apostólica, possuíam a responsabilidade de também designar ou escolher os novos bispos, mas o que nesse momento é importantíssimo ressaltar que houve concretamente uma participação ou, mais precisamente, uma efetiva colaboração da comunidade. Aqui se observa que, no contexto do Novo Testamento, a escolha dos chefes das comunidades era feita por meio dessas duas modalidades ${ }^{20}$, isto é, pelos apóstolos e sucessores, mas tendo sempre a colaboração da comunidade.

Nesse sentido, portanto, afirmar-se-á que, no contexto do Novo Testamento, num primeiro momento, não se encontra uma forma úni$\mathrm{ca}^{21}$ de escolha daqueles que deveriam ser os chefes ${ }^{22}$ das comunida-

17 R. SChnaCKenburg, Participação, 861.

18 Cf. P. StOcKmeIER, A eleição, 8.

19 A importância dos bispos na Igreja primitiva no momento da escolha dos sucessores: «aux origines de l'Église, les apôtres établirent eux-mêmes des évêques. Les disciples immédiats des premiers évêques agiront de même. Par la suite, aux II et III siècles, les évêques d'une province ecclésiastique élisaient les nouveaux evéques avec le concours du clergé et du peuple de l'Église vacante»: R. NAZ, Introduction règles générales des personnes, Paris, 1954, 439.

20 Cf. M. TKHOROVSKYY, Procedura, 10.

21 Cf. M. TKhOROvskyY, Procedura, 11.

22 Cf. E. J. KELTY, The qualities requested of episcopal candidates in the early Church and in the middle ages, Roma, 2006, 65-72. Esse estudo mostra quais e- 
des cristãs. Além disso, a fundamentação e explicação que se podem encontrar acerca da participação da comunidade é que a tradição judaica tinha um grande senso comunitário, que foi herdado pelas comunidades judaico-cristãs do primeiro século.

Depois da composição do Novo Testamento, um dos documentos mais importantes da tradição da Igreja no primeiro século é possivelmente a Didaqué, documento que serviu como espécie de catecismo das primeiras comunidades cristãs e, de certa maneira, ainda representa até hoje importante fonte de ensinamento. Já nesse documento é mencionada a escolha dos bispos numa participação comunitária: «escolham para vocês bispos e diáconos dignos do Senhor. Eles devem ser homens mansos, desprendidos do dinheiro, verazes e provados, porque eles também exercem para vocês o ministério dos profetas e dos mestres» ${ }^{23}$.

Esse documento, especificamente no cânon 15, sobreleva a importância da dignidade do escolhido diante do Senhor, isto é, o testemunho perante Deus, como requisito para o exercício do episcopado: homens que devem ser mansos para poder se relacionar no pastoreio com os fiéis na comunidade, não tendo um espírito de ira ou um comportamento hostil à missão episcopal; devem ser desprendidos de dinheiro, procurando dar o testemunho radical do Senhor que foi humilde e pobre, não buscando riqueza nos bens temporais; sejam homens que busquem a verdade e a vivam em sintonia com sua pregação; devem ser homens que exerçam o ministério de profetas e dos doutores na fé e na tradição profética de Israel. Portanto, homens que deverão ter esses requisitos ${ }^{24}$ para desempenharem o ofício episcopal, em benefício do pastoreio a eles confiado.

ram os requisitos que se levava em consideração para ser bispo no novo testamento.

23 Didaqué, O Catecismo dos primeiros Cristãos para as comunidades de hoje, São Paulo, 1989, n. 15, 1. Esse é um dos primeiros documentos da Igreja Primitiva que procurou elencar requisitos para aqueles que devem desempenhar a função do episcopado e liderança da comunidade. Certamente, feito à luz do percurso neotestamentário nas comunidades cristãs. 


\section{Da carta de são Clemente romano até o início do século IV}

Na Igreja do Ocidente, a Igreja de Roma é a única fundada por apóstolos, Pedro e Paulo ${ }^{25}$. A apostolicidade é muito importante para se entenderem melhor as comunidades primitivas com relação à escolha dos sucessores ${ }^{26}$ dos apóstolos, conferindo-lhe credibilidade na estruturação hierárquica: «a instituição cristã do apóstolo, em seu teor, está marcada primeiramente pela experiência cristã fundamental: pela experiência da Revelação escatológica de Deus em Jesus Cristo, cuja testemunha e mensageiro o apóstolo se torna» ${ }^{27}$. E isso já se observa na carta de são Clemente Romano (35-100) à comunidade de Corinto, que aborda a escolha dos líderes da comunidade: «igitur illos constitutos ab illis vel postmodum a quibusdam viris ornatis consentiente ecclesia omni et ministrantes sine querela gregi Christi cum humilitate et tacite, sine invidia et testimonio reddito multis temporibus ab omnibus, hos estimamus non debere eici ad administratione» ${ }^{28}$.

No final do primeiro e início do segundo século, a referência é a carta de são Clemente, vendo-se perfeitamente que se buscava sempre certa unanimidade na escolha/aprovação daquele que deveria liderar determinada igreja particular. Esta é a conclusão que se extrai da participação do clero e do povo ${ }^{29}$ na escolha dos bispos. Isso representa a exigência do binômio: consenso da igreja = aprovação da comunidade.

25 Cf. J. I. GonsÁlez FAus, Nenhum, 15.

26 Cf. H. M. LegRAND, O sentido teológico das eleições episcopais segundo seu desenrolar na Igreja antiga, in Concilium (1972), n. 77, 879.

27 S. Wiedenhofer, Eclesiologia, in AA. Vv., Manual de Dogmática, Petrópolis, 2001, 122.

28 Clemens, Ad Corinthios Epistula XLIV, in (G. MorIN, cur.), Sancti Clementis Romani ad Corinthios Epistulae versio latina antiquissima, Maredsoli, 1894, 4142. Esse texto muito antigo fala de homens eminentes e dignos, que obtiveram a aprovação de toda a Igreja. Isso nos mostra que havia também a participação da comunidade na escolha dos bispos, como nos apresenta a carta de são Clemente. Cf. J. Eugi, La partecipazione, 51; Cf. M. TKhorovskyy, Procedura, 11; Cf. C. Floristán, A escolha, 260; Cf. J. GAudemet, Storia del Diritto Canonico, Torino, 1998, 470. Esses autores destacam a participação dos membros da comunidade nas escolhas episcopais, isto pe, do clero e do povo. 
Naquele momento histórico o clero era formado por cidadãos que eram presbíteros e diáconos ${ }^{30}$, ao passo que a plebs eram aqueles batizados que faziam parte da comunidade e que não estavam inseridos na hierarquia. Nesse sentido, portanto, tendo como base essa importantíssima carta de são Clemente, exercia-se, pelo clero e pelo povo, um direito fundamental por meio do qual fazia-se uma eleição, que era submetida ao consentimento da comunidade na escolha do seu bispo.

Outro expoente da Patrística, Hipólito de Roma (170-235), relatou a escolha dos bispos no seu livro sobre a "Tradição Apostólica", um século depois de Clemente, procurando também mencionar a participação da comunidade nessa tarefa: «ordinabitur episcopus secundum quod dictum est, electus ab omni popolo, irreprehensibilisis. Qui cum nominatus erit et placuerit eis, populus omnis conveniet et presbyteri et diaconi, die Dominica, episcopis omnibus consentientibus qui imposueurunt manus super eum Presbyteri stabunt» ${ }^{31}$. Essa era a norma de referência que estava presente em âmbito da igreja particular. Essa realidade era maravilhosa ao dizer que se ordenasse o escolhido por toda a plebs, pois certamente a comunidade conhecia bem aquele que iria ser o novo bispo. $\mathrm{O}$ que se percebe, da análise desses textos patrísticos, é que, apesar de alguma tensão nesse processo, procurava-se evitar a interferência de interesses menores ou ambições desmedidas. A imposição das mãos num domingo revela a mais perfeita e completa submissão e aceitação do eleito pela comunidade cristã.

Tudo transcorria no contexto da própria Igreja local, onde se levava em conta o testemunho dos clérigos com relação ao candidato e, por sua vez, o parecer do povo ${ }^{32}$. Essa norma orientava não só a escolha mas também como se deveria proceder à imposição das mãos.

30 Cf. J. EUGI, La partecipazione, 51.

31 H. De Rome, De Episcopi, in (B. BotTe, cur.), Hippolyte de Roma. La tradition apostolique d'après les anciennes versions, Paris, 1968, 40. A ênfase no texto de Hipólito está justamente em que a eleição do Bispo perpassa pela presença de todo o povo que acaba sendo um motivo de tensões: Cf. P. STOCKMEIER, A eleição, 9 .

32 Cf. M. TKhorovskyy, Procedura, 11. 
O iudicium $D e i^{33}$ tinha como elementos essenciais e indispensáveis na escolha dos bispos o povo, o clero e os bispos vizinhos ${ }^{34}$. Esses elementos asseguravam a legitimidade à escolha. Nesse contexto, os bispos vizinhos exerciam uma função de juiz, com a última palavra no percurso da escolha até a consagração, tudo visando garantir que todo o procedimento se desenvolvesse sem maiores problemas, especialmente no que concernia à autonomia na escolha, sem interferência de outra instância de poder.

Orígenes de Alexandria (185-254), contemporâneo de Hipólito, após a conversão, procurou se dedicar a uma vida de oração e estudos bíblicos de modo sistemático. Em uma de suas homilias, comentando o Levítico, faz alusão à escolha dos bispos:

«licet ergo Dominus de constituendo pontifice praecepisset, et Dominus elegisset, tamen convocatur et synagoga. Requiritur enim in ordinando sacerdote et praesentia populi, ut sciant omnes, et certi sint, quia qui praestantior est ex omni populo, qui doctior, qui sanctior, qui in omni virtute eminentior, ille eligitur ad sacerdotium, et hoc astante populo, ne qua postmodum retractatio cuiquam, ne quis scrupulus resideret $\rangle^{35}$.

Orígenes fornece importantes informações, ao afirmar que é chamado ao sacerdócio o mais dotado, o mais sábio, o mais santo, o mais eminente em toda virtude. Além disso, um requisito muito importante é a própria presença do povo, com a finalidade de evitar retratações e/ou problemas que porventura pudessem surgir futuramente. Eis porque foi dada uma atenção particular a essa homilia, buscandose evitar maiores problemas de natureza eclesial.

\footnotetext{
Cf. J. EuGI, La partecipazione, 58-59.

Cf. C. Floristán, A escolha, 260; Cf. J. I. Gonsález Faus, Nenhum, 19.

5 Origenes, In Leviticum Homilia VI, 3, in (J.-P. Migne, cur.), Patrologiae cursus completus. Series Graeca, XII, Paris, 1862, coll. 469.
} 
Nos «séculos II e III tomavam parte na eleição do novo bispo os bispos da mesma província eclesiástica, o presbitério e o povo» ${ }^{36}$. Portanto, a partir desses séculos se inicia um modelo de se escolherem os bispos de quase todas as regiões, pelo menos até o final do período da Igreja Antiga, levando em consideração três elementos: «o povo de cada Igreja, o presbitério local e os bispos circunvizinhos» ${ }^{37}$. Essa característica também se faz presente em Cipriano de Cartago (258):

«Episcopi eiusdem provinciae proximi quique conveniant, et episcopus deligatur plebe praesente, quae singulorum vitam plenissime novit et uniuscuiusque actum de illius conversatione perspexit. Quod et apud vos factum videmus in Sabini Collegae nostri ordinatione, ut de universae fraternitatis suffragio et de episcoporum, qui in praesentia conveneant quique de eo ad vos litteras fecerant, iudicio episcopatus ei deferretur et manus ei in locum Basilidis imponeretur» ${ }^{38}$.

São Cipriano procura enumerar aqueles elementos que iriam garantir a escolha válida do bispo, referindo-se justamente à presença dos bispos vizinhos, e também a comunidade local, ou seja, pelo sufrágio de toda a fraternidade (suffragio). Isso nos mostra que de fato ocorreu uma comunhão e uma participação dos clérigos e leigos nas designações episcopais mediante toda essa realidade eclesiológica.

Vejamos outro texto do próprio Cipriano: «factus est autem Cornelius episcopus de Dei et Christi eius iudicio, de clericorum pae-

36 G. GhirlandA, O direito na Igreja. Mistério de comunhão, Aparecida, 2003, 602. Esses três elementos, a partir desse momento, começam a ser preponderantes nas escolhas episcopais. Pois outro autor sustenta que «è necessario, a questo punto, sottolineare l'importanza del ruolo costitutivo del popolo, del clero e dei Vescovi nello svolgimento della designazione, considerati como elementi indispensabili per la sua legittimità e come l'espressione unanime del iudicium Dei»: M. TKHOROVSKYY, Procedura, 12.

37 J. I. GONSÁlEZ FAUS, Nenhum, 19.

38 CYPRIANUS, Epistolae 67,5, in (M. J. ROUËT DE JOURNEL, cur.), Enchiridion Patristicum, n. 588, Paris, 1946, 208. 
ne omnium testimonio, de plebis quae tunc adfuit suffragio, de sacerdotum antiquorum et bonorum virorum collegio»» ${ }^{39}$. Segundo Congar, são Cipriano nos mostra: «o julgamento de Deus, o bom testemunho dos clérigos, o sufrágio do povo, o consentimento dos demais bispos» ${ }^{40}$, exatamente para garantir a eleição daquele que fosse o mais apto para o ministério episcopal. Essa ação eclesial de toda a Igreja reunida era revestida da presença divina que os leva à essa dimensão eclesial de ver a Igreja reunida em harmonia e autoridade. De fato, aqui estamos em um momento no qual o princípio eletivo chega a um grau de participação e colaboração e essa práxis vai constituindo uma parte da tradição eclesial.

Nesses textos, os clérigos e os fiéis leigos são levados muito a sério, porque eles não davam simplesmente um consentimento, mas participavam na escolha do novo epíscopo. «No entanto seria errônea ver na consulta do povo um expediente político» ${ }^{41}$. Evidentemente, havia uma certa supervisão nas escolhas episcopais, para evitar abusos e corrupções que pudessem ocorrer, seja por parte da comunidade ou por parte de clérigos, ou até mesmo pela manipulação daqueles que estavam interessados em ser nomeados bispos. Diante disso, percebese que são Cipriano aludiu, segundo a interpretação de Faus «que considera a designação pelo povo como idêntica à designação por Deus: escolher sem contar com o povo é eleger "sem contar com Deus". Poucas vezes se tomou tão a sério o célebre refrão: "Vox populi, vox Dei» ${ }^{42}$.

Evidentemente, deve-se esclarecer que a construção desse princípio eletivo não pode ser comparado com as formas eleitorais dos estados modernos, apresentam intrinsecamente esse princípio da competição e das campanhas desenvolvidas por cada candidato, podendo ocorrer manipulações e compra de posições. Nesse sentido, podemos dizer que o termo suffragium não é o mesmo que votar ou eleger como

39 CYPRIANUS, Epistolae 55, 8, in (M. J. ROUËT DE JOURNEL, cur.), Enchiridion Patristicum, n. 575, Paris, 1946, 206.

40 Y. M. J. CONGAR, Os leigos na Igreja. Escalóes para uma teologia do laicato, São Paulo, 1966, 346.

41 A. FAIVRe, Os leigos na origem da Igreja, Petrópolis, 1992, 138.

42 J. I. GONSÁlEZ FAUS, Nenhum, 21. 
se entende nos dias de hoje, mas que a comunidade leva o seu voto ou o testemunho acerca de alguém que goza de muita credibilidade.

São Cipriano, em suas cartas, destacou a distinção da figura dos bispos, presbíteros e diáconos ${ }^{43}$. Além disso, no meio do século III e IV, temos uma teologia consolidada sobre o episcopado ${ }^{44}$, na qual os ministérios estavam estruturados concebendo cada bispo como sucessor dos apóstolos ${ }^{45}$ e podendo-se observar que a comunidade participava muito na atividade episcopal. Dessa forma, nas cartas ciprianas, encontramos muitos termos merecedores de muita atenção: suffragium plebis, visto como o voto dos fiéis da comunidade; suffragium que era de toda a comunidade e do clero; suffragium populi e suffragium fraternitatis, sendo o voto da comunidade e o do clero ${ }^{46}$. Isso sem falar outro termo, testimonium, para se referir ao clero e à comunidade lo$\mathrm{cal}^{47}$. Por isso, é necessário verificar qual o sentido do termo suffragium em são Cipriano e em outras fontes que falam das designações episcopais, utilizando-se dos estudos etimológico, teológico e histórico nas fontes possíveis de se analisar.

\section{A influência da estrutura imperial passando pelos concílios e metropolitas}

No século IV, com a figura do Imperador Constantino, a Igreja vai sendo influenciada por uma estrutura administrativa herdada do Império Romano. Isso ocorreu com as "províncias eclesiásticas" e as pequenas dioceses nas regiões em que os bispos tinham jurisdição. $\mathrm{O}$ Império foi sendo dividido em províncias, e de certa forma as regiões episcopais acompanharam essas divisões ${ }^{48}$. No inicio daquele século, ocorreu uma mudança ${ }^{49}$ crucial nas eleições episcopais. De um lado,

43 Cf. J. I. GonsÁlez FAUs, Nenhum, 21.

44 M. TKhorovskyY, Procedura, 12. Vale dizer que ocorreu uma evolução teológica durante esses primeiros séculos, havendo uma estruturação e fundamentação teológica do episcopado.

Cf. J. I. GonsÁlez FAus, Nenhum, 25.

46 Cf. J. Eugi, La partecipazione, 51.

47 Cf. J. Eugi, La partecipazione, 51.

48 Cf. C. Floristán, A escolha, 260.

49 Cf. M. TKhorovskyy, Procedura, 12. 
os bispos tinham uma importância política e social muito grande. Isso acabava despertando o interesse da autoridade civil nas eleições episcopais e se tornava um objeto de ambição ${ }^{50}$ por parte desse poder temporal. Ao que parece, essa era preocupação primeira uma vez que os bispos tiveram seu poder ampliado e uma grande influência naquele contexto religioso, adquirindo importante posição social, político e econômico.

Certamente, a Igreja começa a se preocupar com isso, ao perceber certo perigo nas futuras designações episcopais, dado o grande interesse e ambição por parte de muitos. A preocupação da Igreja era muito procedente, pois as novas designações poderiam ocorrer de forma corrupta ou até mesmo de modo ilícito, com consequências negativas do ponto de vista espiritual para leigos e clérigos. De qualquer forma, esse era o grande desafio que a Igreja começava a enfrentar no início do século IV. Com isso, aqueles que até então eram os protagonistas das designações episcopais bispos, clérigos e povo, percebiam o risco desse princípio eletivo, embora fizessem a escolha na presença de Deus e de sua Igreja ${ }^{51}$, pois tudo era realizado em um espírito de comunhão e corresponsabilidade entre os membros da Igreja, mesmo com seus desafios e obstáculos.

Outra modalidade que fosse diferente daquela que a Igreja, em vários lugares, tinha utilizado para escolher os bispos por meio do princípio eletivo não expressaria a vontade de Deus. Essa escolha estava ameaçada e comprometida, embora se vivenciasse uma verdadeira eclesiologia dos primeiros séculos. Havia o risco de as designações se tornarem e se resumirem em objetos de sujeitos particulares ${ }^{52}$ que ameaçam realmente a missão da Igreja.

Ainda no século IV, dispomos de prelados ilustres como Ambrósio, Agostinho, que teriam a ajuda do primaz de Cartago e dos bispos daquela região. A partir desse século, o metropolita foi ganhando importância ${ }^{53}$ : Germano de Auxerre, são Jerônimo, o papa Dâmaso e

\footnotetext{
50 Cf. J. I. GonsÁlez FAUS, Nenhum, 25.

51 Cf. J. I. GonsÁlez FAus, Nenhum, 25.

52 Cf. J. I. GonsÁlez FAUS, Nenhum, 25.

53 Cf. K. Schatz, Eleccion de Obispos. Historia y teologia, Barcelona, 1991, 104;

Cf. C. Floristán, A escolha, 261.
} 
tantos outros. Esses bispos foram grandes personalidades em suas "dioceses", no que diz respeito ao ofício episcopal. Gaudemet nos diz, por exemplo, que «Ambrósio foi escolhido pelo povo» ${ }^{54}$. Observemos um texto que fala da eleição de Ambrósio no ano de 355 para o bispado de Milão:«[...] Cumque inibi multa secundum leges et publicam disciplinam pro quiete et tranquillitate perosasset, pugnantis inter se et dissidentis populi subito clamor et vox una consurgit, Ambrosium Episcopum postulantes[...]» ${ }^{55}$.

Ambrósio era cônsul e tinha boa reputação entre os cidadãos, os quais pediram fosse o novo Bispo, mas teria que ser batizado porque era ainda catecúmeno. Nesse contexto, o povo exerceu a função de juiz, pois o imperador ficava muito atento porque se fazia necessário respeitar aquilo que era aclamado pelo povo. Portanto, houve uma verdadeira aclamação popular que deveria ser levada em consideração pela autoridade civil e, caso ele não fosse escolhido, a cidade ficaria prejudicada.

O cristianismo dessa época estava se integrando ao estado romano; a função do bispo passa a ter maior interesse da classe alta do Império ${ }^{56}$. No governo de Constantino, ocorreu o Concílio mais importante que foi o de Nicéia, no ano de 325 d.C, estabelecendo no cânon n. 4: «Episcopum convenit maxime quidam ab omnibus qui sunt in provincia episcopis ordinari. Si autem hoc difficile fuerit, aut propter instantem necessitatem aut propter itineris longitudinem: modis omnibus tamen tribus in id ipsum convenientibus et absentibus episcopis pariter decernentibus et per scripta consentientibus tunc ordinatio celebretur» ${ }^{57}$.

Essa norma do Concílio de Nicéia, estabelecia que a eleição do bispo fosse feita pelos bispos da região vizinha ${ }^{58}$, ou seja, da provín-

54 J. GAUDEMET, A escolha dos bispos: uma história atormentada, in Concilium (1996), n. 267, 79.

55 Ambrosius, Epistolae XI, caput XI, in (J.-P. Migne, cur.), Patrologiae cursus completus. Series Latina, XXI, Paris, 1865, 521-522.

56 Cf. P. STOCKMEIER, A eleição, 12.

57 Concilium Oecumenicum NicAenum, can. 4, in (G. Alberigo et Alit, curr.), Conciliorum Oecumenicorum Decreta, Bologna, 1996, 7.

58 Cf. P. STOCKMEIER, A eleição, 12; para maior ênfase e aprofundamento sobre a escolha dos bispos no Concílio de Nicéia: «Le concile de Nicée (325) décida que 
cia. E também fosse ordenado por três bispos ou mais, sendo que os bispos que estivessem ausentes, deveriam justificar por escrito, a ausência. Essa normativa do cânon 4 dizia que se devia observar a participação dos bispos na ordenação, sendo mesmo um elemento integrante da nomeação ${ }^{59}$. Esse cânon destacou o aspecto colegial do episcopado visando evitar abusos e pretensões particulares, por parte até mesmo do imperador e de clérigos, ou do metropolita.

Além disso, o cânon 6 do mesmo Concílio, normatizou que a escolha do bispo deveria ter a confirmação do metropolita, sem qual o escolhido não poderia ser consagrado. Naturalmente, essa normativa nasceu visando evitar abusos e irregularidades por parte dos bispos e de outras autoridades, mas ao mesmo tempo procurou impor limites ao papel do metropolita e também reconhecer a sua aprovação com relação à designação de um novo bispo.

Dessa forma, houve no século IV vários concílios que se preocuparam com as designações episcopais, que ocorreram depois de Nicéia e puderam confirmar a decisão tomada em 325 sobre esse assunto. Esse tema era central na vida da Igreja nesses primeiros séculos e, na verdade, sempre foi uma preocupação das igrejas locais, de modo que, com o passar do tempo, a normativa foi se modificando e acrescentando outros elementos de importância para atender aquele determinado período de desafio que a Igreja viveu na história.

Com relação aos concílios daquele século, temos, de um lado, o Concílio de Arles $^{60}$ em 314, que alude à presença de sete bispos presentes ou pelo menos três para a consagração. Em Antioquia, na Síria $^{61}$, no ano de 341 , enfatiza-se o aspecto da colegialidade episcopal,

l'élection des évêques serait faite par les évêques de la même province ecclésiastique et serait confirmée par le métropolitain. La même discipline fut observée dans l'église d'Occident, du IV au VI siècle. A la même époque, se produisit soit par usurpation, soit aussi parfois par concession de l'Église, l'intervention des empereurs et des rois dans la nomination des évêques, surtout en France, en Allemagne et en Espagne»: R. NAZ, Introduction, 439-440; A intervenção de todos os bispos da província e naturalmente a confirmação do metropolita: Cf. J. EUGI, La partecipazione, 53.

59 Cf. M. TKHOROVSKYy, Procedura, 14.

60 Cf. J. I. Gonsález FAUS, Nenhum, 25.

61 Cf. J. I. GonsÁlez FAus, Nenhum, 27; Cf. Na Síria houve esse Concílio de Antioquia que tinha como prática jurídica universal o estabelecido no cânon 16 , o 
ao dizer que ninguém poderia ser ordenado bispo sem a ausência do Sínodo. Já em Ancira ${ }^{62}$, em outro Sínodo, no ano de 314, abordou-se a importância daqueles bispos escolhidos que, se não fossem aceitos no território para os quais haviam sido designados e, de certa forma, quisessem ir para outras Igrejas, deveriam ser expulsos.

\section{A tentativa do retorno do princípio eletivo no início do século $\mathrm{V}$}

No século V, temos uma intervenção do papa Celestino I (428), o qual reafirma o princípio da participação do povo na eleição episcopal, preservando esse princípio eletivo para que o povo não fosse contrariado: «nullus invictus detur episcopus, cleri, plebis et ordinis, consensus ac desiderium requiratur $\gg{ }^{63}$. Nesse texto, ao que parece, fez-se uma precisão, levando em consideração o consenso entre o povo e os eclesiásticos. Dessa forma, nos mostra que havia a necessidade de um consentimento de toda a Igreja. Certamente, aquí reside uma grande preocupação do papa Celestino I: que o povo não fosse substituído pelos nobres ou por homens públicos. Portanto, houve uma tentativa para que o povo e os clérigos não fossem trocados pelo poder civil, que iria trazer muitos danos ${ }^{64}$ para a Igreja.

A carta de Possídio procura reafirmar também o consentimento dos cristãos, isso porque, já no século $\mathrm{V}$, ocorria como prática fundamental da tradição da Igreja. "In ordinandis vero sacerdotibus et clericis consensum majorem (a) christianorum, et consuetudiem Ecclesiae sequendam arbitrabatur» ${ }^{65}$. De fato, «o século V representa o momento de maior afirmação do princípio eletivo, com a consagração da fórmula clássica que voltaremos a encontrar: "clerus populusque»" ${ }^{66}$.

qual afirmava que se deixava para deferir sobre a nomeação episcopal, quando os bispos estivessem reunidos: Cf. M. TKHOROVSKYY, Procedura, 13.

Cf. J. I. GonsÁlez FAus, Nenhum, 27.

63 Celestinus I, Epistola ad Episcopos Viennenses, caput. 5, in (J.-P. Migne, cur.), Patrologiae cursus completus. Series Latina, L, Paris, 1865, coll. 434.

64 Cf. J. I. GonsÁlez FAUS, Nenhum, 36.

65 Possidius, Vita Santi Augustini, caput. 21, in (J.-P. Migne, cur.), Patrologiae cursus completus. Series Latina, XXXII, Paris, 1877, coll. 51.

66 J. I. GONSÁlEZ FAUS, Nenhum, 43. 
De um lado, o interesse, por parte da Igreja, em recorrer ao princípio eletivo. Essa foi uma das tentativas de combater os abusos por parte da autoridade civil. Por outro lado, século $\mathrm{V}$, pode-se observar a tentativa de uma maior ingerência por parte do poder civil nas designações episcopais, seja do imperador ${ }^{67}$ ou dos seus representantes. Isso demonstra que os imperadores tinham muito interesse na nomeação dos bispos. Contra essa tendência, para garantir maior liberdade da Igreja nessa matéria de nomeações episcopais, os metropolitas e muitos eclesiásticos combateram essa ingerência do poder civil, até porque o papa se encontrava longe pelas distâncias e pela comunicação, não podendo acompanhar a problemática de cada região em tempo real. Tudo para assegurar maior liberdade da Igreja, que juntamente com o clero e o povo, poderia participar nas designações episcopais.

$\mathrm{Na}$ metade do século $\mathrm{V}$, tem-se a contribuição do papa Leão Magno (440-461), que disse que a eleição episcopal deveria ser realizada também pelo clero e pelo povo: «per pacem et quietem sacerdotes qui futuri sunt postulentur. Teneatur subscriptio clericorum, honoratorum testimonium, ordinis consensus et plebis. Qui praefuturus est omnibus, ab omnibus eligatur» ${ }^{68}$. Essa bela afirmação sobre a escolha dos bispos nos faz perceber que o candidato deveria ser eleito pelo princípio eletivo, pois aquele que estaria à frente de todos como pastor cuidando do seu povo, deveria ter o consenso da maioria. Nesse texto, observa-se outro exemplo e outra tentativa para se livrar da ingerência do poder civil que, nessa concepção, traria muitos danos para a Igreja. Além disso, ressalte-se a tentativa do papa Leão Magno em reforçar as nomeações episcopais, dando destaque e direito às igrejas locais ${ }^{69}$.

Vejamos outra passagem em que o metropolita só pode ordenar um sacerdote ao episcopado caso seja eleito pelo clero e pelo povo, e somente assim poderá ser ordenado: «nulli prorsus metropolitae hoc licere permittimus, ut suo tantum arbitrio, sine cleri et plebis assensu quemquam ordinet sacerdotem; sed eum Ecclesiae Dei praeficiat,

\footnotetext{
Cf. M. TKHOROVSKYY, Procedura, 14.

68 Leo Magnus, Epistolae X, ad Episcopum Viennae, caput 6, in (J.-P. Migne, cur.), Patrologiae cursus completus. Series Latina, LIV, Paris, 1881, coll. 634.

Cf. C. Floristán, A escolha, 261.
} 
quem totius civitatis consensus elegerit» ${ }^{70}$. Nesse texto, o metropolita não pode levar em consideração somente seu juízo para proceder à ordenação, mas o consenso do povo e do clero. Dessa forma, vai garantir aquilo que se propunha realizar à luz do princípio eletivo e toda a Igreja local podia observar e realizar a mediação para se chegar ao clérigo ideal para o exercício do episcopado, pois seu múnus implica governar por aquele que foi escolhido por todos.

É evidente que aqui, neste trabalho, não é possível citar todos os textos do período antigo da Igreja, que trazem, na práxis da época, a participação dos clérigos e dos leigos, do metropolita na eleição de um bispo. De qualquer forma, «o clero e povo eram uma unidade básica de culto comunitário e participação nas celebrações litúrgicas» ${ }^{71}$. Portanto, nesses primeiros séculos da vida da Igreja ocorre um protagonismo das «comunidades locais que participavam evidentemente na indicação de diáconos, presbíteros e bispos, seja por eleição direta, seja por aclamação ou testemunhas»» ${ }^{72}$. Esses casos foram ficando cada vez mais raros nos séculos seguintes, uma vez que o poder civil teve mais influência na vida da Igreja, sendo o episcopado de grande interesse de imperadores, reis, príncipes, nobres em geral.

Destarte, procurou-se abordar apenas alguns textos da Igreja Primitiva, porém muito importantes para a tradição da Igreja, pois trazem o significado de "electio", "consensus" e "receptio", que são três atos vitais para a Igreja primitiva: «a eleição como modo de escolha dos bispos da comunidade, o consenso como manifestação grupal de uma comunhão ativa em assuntos específicos, a recepção enquanto ato explícito de aceitação de decisões tomadas em consenso de quem realiza a recepção» ${ }^{73}$.

A eleição, o consenso e a recepção são características centrais que marcam o início da Igreja, como terminologias usadas nos textos antigos para expressar a escolha dos bispos ${ }^{74}$. Tudo isso nos mostra

70 Leo Magnus, Epistolae XIV, ad Episcopum Iliria, caput 3, in (J.-P. Migne, cur.), $P L$, coll. 665 .

71 D. KnOwles, Nova história da Igreja II, Petrópolis, 1974, 280.

72 R. KotTue, A escolha, 348.

73 G. Alberigo, A Igreja na História, São Paulo, 1999, 35.

74 Cf. R. SchnaCKenBURG, Participação, 856. 
que essas expressões têm uma conotação sinônima ${ }^{75}$. De modo que, «na Igreja dos primeiros séculos, a escolha dos responsáveis pelas igrejas e, concretamente, dos bispos, constitui um direito fundamental do clero e do povo» ${ }^{76}$.

\section{Maior ingerência do poder temporal nas escolhas episcopais após o século VI}

Nos séculos VI e VII, a eleição dos bispos, que era realizada pelo clero e pelo povo, vai sendo substituída por uma eleição exclusivamente clerical e aristocrática ${ }^{77}$ e as "nomeações episcopais não apenas os bispos, mas os príncipes e outros senhores feudais, que substituíram o clero e o povo» ${ }^{78}$. Diante dessa grande mudança, a Igreja vai defender sua liberdade nas designações episcopais contra os abusos nas eleições. $\mathrm{O}$ episcopado agora tem maior interesse para os reis na $\mathrm{Eu}-$ ropa, que usurparam o direito do povo, do clero e dos metropolitas e de cada bispo poder nomear o seu sucessor ${ }^{79}$.

Em 572, tivemos o segundo Concílio local, realizado em Braga, com a participação de 12 bispos e procurou recorrer a um cânon dos antigos padres orientais, pois se dizia no De electione episcopi: «non liceat populo electionem facere eorum qui ad sacerdotium provocantur, sed iudicium sit episcoporum, ut ipsi eum qui ordinandus est probent, si in sermone et fide et in spirituali vita edoctus est» ${ }^{80}$. Diante disso, o povo vai ficando de lado no que diz respeito à eleição dos bispos, mas aqui estamos fazendo referência ao contexto da Igreja no Oriente, que de fato, estavam ficando reservadas aos bispos as escolhas episcopais. Mesmo assim, vai sendo excluído propriamente a participação do povo, embora essa prática, segundo o Concílio de Braga, não fosse uma legislação para toda a Igreja.

75 Cf. G. BARTELINK, "Eleição” e "consensus" na linguagem cristã (até cerca do ano 600), in Concilium (1972), n. 77, 977.

76 Cf. C. Floristán, A escolha, 259.

77 Cf. J. I. GonsÁlez FAUS, Nenhum, 50.

78 C. FLORISTÁn, A escolha, 261.

79 Cf. M. TKhorovskyY, Procedura, 15.

80 Concilium Bragaense (572), in (J. ViVes, cur.), Concilios visigoticos e hispano-romanos, Barcelona-Madrid, I, 1963, 86. 
O próprio papa Gregório Magno (590-604) foi um homem de governo minucioso e respeitoso ${ }^{81}$. Em sua obra, "Regra Pastoral", defendia a liberdade das igrejas particulares, que lhes fosse dado eleger seus próprios bispos, o que seria enfatizado em algumas regiões nos séculos sucessivos: "constantemente lembrou-se, entre os séculos VI e XI, que a escolha dos bispos era um direito tradicional do clero e do povo com o consentimento do metropolita» ${ }^{82}$. Entretanto, nesse período essa prerrogativa foi sendo deixada de lado, mas as igrejas locais reivindicavam o direito de retornar ao principio eletivo que cada vez mais foi ficando distante.

O papa Gregório Magno era muito atento ministério episcopal. Ele defendia, como requisito para a designação episcopal, a capacidade espiritual e intelectual ${ }^{83}$ daqueles que poderiam ser designados. Além do mais, a dignidade do candidato era muito importante e deveria ser levada em consideração. Sua obra "Regra Pastoral" representa um pequeno tratado sobre o exercício da função episcopal, já que esse ministério deveria ser encarado como serviço propriamente dito e não como uma honra. No pastoreio, esse papa pode tratar vários assuntos dessa natureza por meio de suas cartas expedidas.

Certamente, o papa Gregório Magno queria bispos dedicados e que se enquadrassem no ensinamento acima referido. Para procurar pelo clérigo justo e ideal para o serviço do episcopado, o papa nomeava um visitador ${ }^{84}$ que visitaria as igrejas, de maneira que as normas da Igreja ser observadas. Esse visitador tinha as orientações que deveria se ocupar nessa missão que desempenhava diante de uma nomeação papal. O visitador deveria procurar por uma pessoa digna desse ministério, que tivesse o consentimento do clero e do povo e, mais que não fosse recusado pelos veneráveis cânones ${ }^{85}$.

Aqui se observa uma grande tentativa de retorno ao principio eletivo, tendo em vista a eficiência nos procedimentos pela busca de uma pessoa digna para o episcopado. Sem dúvida, percebe-se uma

\footnotetext{
81 Cf. J. I. Gonsález FAUS, Nenhum, 58.

82 C. Floristán, A escolha, 261.

83 Cf. M. TKhorovskyy, Procedura, 16.

84 Cf. J. I. GonsÁlez FAUS, Nenhum, 58.

85 Cf. J. I. GonsÁlez FAUS, Nenhum, 58-59.
} 
eclesiologia que leva em consideração elementos profundamente em sintonia com a verdadeira tradição da Igreja, que não queria que fosse usurpada e se tornasse objeto de interesses escusos, seja por parte de poderes civis ou por parte de clérigos.

Finalmente, quando alguém era escolhido, segundo as orientações dessas cartas do papa Gregório Magno, o escolhido deveria ser apresentado ao metropolita e não ao papa. Diante disso, com todas essas medidas, o papa quis fortalecer a Igreja em sua forma intestina, ou seja, no interior da instituição, contra os interesses do poder temporal, isto é, do interesse políticos dos reis, ao ponto de ter orientado em suas cartas que não fosse escolhido um leigo para o exercício do episcopado e muito menos que o episcopado fosse algo que pudesse ser comprado, configurando-se a simonia. Alguém, que chegasse a ser bispo por meio do dinheiro, faltaria honestidade e capacidade para exercer esse ministério tão sublime e importante na vida da Igreja.

Ainda no século VI, na Gália, com a conversão dos reis fran$\cos ^{86}$, que se interessavam pela nomeação de bispos, foi deixado de lado aquilo que a Igreja vinha decidindo nos séculos anteriores. Por isso, os concílios realizados na região estavam indo contra dois aspectos: contra a intervenção do rei e a simonia. De um lado, tivemos o II Concílio de Orléans, em 533, que era contrário ao poder civil, considerando como simonia no cânon 4. Além desse, o V Concílio de Orléans, em 549, buscava se posicionar contra a política merovíngia que interferia nas eleições episcopais. Em outra tentativa, agora do III Concílio de Paris, em 557, no cânon 8, buscava-se eliminar o poder real e instaurar e eleição canônica ${ }^{87}$. Não poderia deixar de mencionar o V Concilio de Paris, em 615, segundo o qual, enquanto vivesse o bispo, não se punha outro. Finalmente, o Concílio de Reims, em 635 ou 639 , no cânon 25 , determinava que, ao morre um bispo, punha-se outro no seu lugar com o voto de todos: povo e clérigos ${ }^{88}$.

86 Cf. J. I. GonsÁlez Faus, Nenhum, 51; 55-57; Cf. M. TKhorovskyy, Procedu$\mathrm{ra}, 15$.

87 Cf. M. TKhorovskyY, Procedura, 15.

88 Cf. J. I. GonsÁlez FAUS, Nenhum, 57. 
No século VII na Espanha, com os visigodos, a escolha dos bispos se tornou objeto de negociações dos reis ${ }^{89}$. Assim sendo, naquele século, temos os concílios hispânicos que também abordaram a escolha dos bispos; como também o IV Concílio de Toledo, ocorrido em 633, que contou com a presença dos episcopados espanhol e francês, reunindo um total de 66 bispos, que afirmaram no cânon 19: «perniciosa consuetudo nequaquam est reticenda, quae maiorum statuta praeteriens omnem ecclesiae ordinem perturbavit, dum alii per ambitum sacerdotia appetunt, alii oblatis muneribus pontificatum adsummunt, nonnulli etiam sceleribus inplicati vel seculari militiae dediti indigni ad honorem sumi ac sacri ordinis pervenerunt $[\ldots]\rangle^{90}$.

Isso nos mostra que o episcopado vai se tornando objeto de interesses daqueles que almejam o poder. Esses, embora violando a tradição por meio de subornos e crimes, chegam ao episcopado. Os que poderão ser bispos não estejam envolvidos em crimes. Essa era a normativa do Concílio, que enfatizava a deposição dos candidatos que se encontrassem em tal situação. Essas condições são mencionadas como procedimentos a serem respeitados para todos os candidatos e, caso não se respeitassem, ocorreria aquilo que foi chamado de perturbação para toda a Igreja.

Ainda na Espanha, em 681, ocorreu o XII Concílio de Toledo. Encontra-se em suas atas o discurso para os bispos do rei Ervígio ${ }^{91}$, mostrando a influência dos reis na vida da Igreja, porque se demorava muito para avisar ao rei sobre o falecimento de um bispo. Com isso, os bispos tinham liberdade na nomeação de outros bispos. É o que nos adverte o cânon 6 :

«unde placuit omnibus pontificibus Spaniae et Galliae, ut salvo privilegio uniuscuiusque provinciae licitum maneat deinceps Toletano pontifici quosquunque regalis potestas elegerit et iamdicti Toletani episcopi iudicium dignos esse probaverit, in quibus-

89 Cf. G. GHIRLANDA, $O$ direito, 602.

90 Concilium Toletanum (633), in (J. Vives, cur.), Concilios visigoticos e hispano-romanos, Barcelona-Madrid, I, 1963, 198-199.

91 Cf. J. I. GonsÁlez FAus, Nenhum, 54. 
libet provinciis in praecedentium sedium praeficere praesules et desidentibus episcopis eligere successores» ${ }^{92}$.

Esse cânon demonstrou perfeitamente que as nomeações episcopais que antes eram realizadas pelo clero e pelo povo, mesmo com ingerências nas designações episcopais pelo poder temporal; agora esse direito «ficou reduzido ao arcebispo de Toledo e ao rei»" ${ }^{93}$, ou «em outras palavras: o "clero e o povo" passa a ser reduzido simplesmente ao bispo e ao rei» ${ }^{94}$. A partir de então, os reis, príncipes, nobres, aristocratas influenciarão cada vez mais nas nomeações dos bispos ${ }^{95}$. As decisões dos reis nas nomeações episcopais se davam devido aos interesses políticos e econômicos que exerciam sobre os bispados. Normalmente, esses bispados produziam boas "rendas"96, daí o grande interesse dos reis. Além disso, os bispos gozavam de um status e de muito respeito frente às várias realidades que os rodeavam.

\section{A pluralidade e a complexidade das escolhas episcopais desde o século VIII}

A partir do século VIII até o século X, a escolha dos bispos vai tomando uma dimensão plural, isto é, são várias formas de eleição, de sorte que a prática na escolha dos bispos já não é mais uniforme ${ }^{97}$. Nessa época, a forma predominante da nomeação era realizada por

92 Concilium Toletanum (681), in (J. Vives, cur.), Concilios visigoticos e hispano-romanos, Barcelona-Madrid, I, 1963, 394.

93 J. I. GONSÁlEZ FAUS, Nenhum, 55.

94 J. I. GONSÁLEZ FAUS, Nenhum, 51.

95 Cf. C. Floristán, A escolha, 261; Cf. G. Alberigo, A Igreja, 40; Cf. P. HuIZING - K. WALF, Editorial, in Concilium (1980), n. 157, 3; Cf. H. M. LEGRAND, O sentido, 877; Cf. W. KÖLMEL, As eleições episcopais e os poderes políticos: em que medida as eleições episcopais deram ensejo a manipulações por parte dos poderes políticos, in Concilium (1972), n. 77, 910; Cf. W. UlLmanN, Os Reis da França e a eleição dos bispos nos séculos IX e X, in Concilium (1972), n. 77, 918; Cf. A. Melloni, Como se elege um papa: a história do conclave, São Paulo, 2002, 27.

96 Cf. C. Floristán, A escolha, 262.

97 Cf. J. I. GonsÁlez FAus, Nenhum, 65; Cf. M. TKhorovskyy, Procedura, 16. 
parte do poder civil, nada obstante os muitos protestos com o intuito de retornar às origens da Igreja, justamente para sanar os interesses escusos já mencionados. Portanto, não é possível encontrar nesse tempo, uma práxis uniforme ${ }^{98}$ de designações episcopais, pois é exatamente diante dessa realidade que a Igreja tem o profundo desejo de ser fiel à tradição.

Por isso, tem-se dificuldade de seguir uma ordem cronológica a partir desse período. Nesse sentido, fica mais fácil poder abordar, a partir de alguns concílios ecumênicos, as contestações proféticas pessoais, as situações de igrejas particulares, a presença dos reis e príncipes, somando ainda a práxis de fazer apelações para Roma ${ }^{99}$. Dessa forma, temos essas principais características que marcaram as designações episcopais nesses séculos, mas vale a pena enfatizar que houve muitas tentativas de impedir que reis, príncipes e outras autoridades civis tomassem parte nessa matéria eclesiástica. Pois ela tinha sido muito bem trabalhada em tantos momentos eclesiais, seja nos concílios, sínodos ou em várias igrejas locais.

A Igreja buscava sua renovação e a liberdade diante desses poderes civis, que resistiam no seu interesse de escolha, em razão dos efeitos econômicos e de autoridade e, por isso mesmo, sobrelevavam ambições desmedidas em um ministério que deveria exigir uma atenção especial, por conta da sua finalidade pastoral. A conquista por parte da autoridade eclesial ia ficando cada vez mais comprometida, tendo presente que boa parte de vários reinos estava muito interessada nas escolhas episcopais, daí porque se verificava grande resistência, porque o poder temporal não admitia a influência ou ingerência no processo de escolha episcopal. Apesar disso, em alguns reinos se respeitava buscar candidatos verdadeiramente idôneos o que garantia o direito de nomear os bispos: "nell'impero franco occidentale si affermò il diritto di nominare i Vescovi ex palatio, con la sola condizione che $i$ candidati fossero canonicamente idonei» ${ }^{100}$.

No ano de 787 ocorreu o Concílio Ecumênico de Nicéia (II), quando as autoridades eclesiásticas decidiram que os governantes não

98 Cf. M. TKhOROVSKYY, Procedura, 16.

99 Cf. J. I. GonsÁlez FAUs, Nenhum, 65.

100 M. TKhorovskyY, Procedura, 17. 
podiam mais escolher seus bispos sob pena de invalidade: «Oportet enim ut qui provehendus est in episcopum, ab episcopis eligatur; quemadmodum a sanctis patribus qui apud Nicaeam convenerunt, in regula definitum est, quae dicit» ${ }^{101}$.

Aqui temos uma retomada do Concílio de Nicéia que foi uma grande referência para os concílios posteriores na matéria de designação de bispos. A preocupação do Nicéia II era frear os abusos por parte dos leigos, ou mais propriamente, os governantes que haviam subtraído dos clérigos e leigos o princípio eletivo tão bem constituído pela Igreja no passado. A Igreja era alvo de usurpações e abusos com relação às designações episcopais. De um lado tinha acontecido uma estratificação da sociedade, onde somente os senhores eram considerados cidadãos ${ }^{102}$. De outro lado, estava ocorrendo a chamada clericalização na vida da Igreja. Por isso, se fazia necessário buscar, por parte do concílio, a liberdade diante dessas autoridades civis que estavam destruindo e impedindo um eficiente trabalho eclesial por parte dos bispos.

Nesse aspecto, deve-se enfatizar a dimensão jurídica desse cânon. As designações episcopais ou mesmo as outras ordens vinham sendo objeto de manipulação por parte de autoridades civis, por isso que, a Igreja, buscando solucionar esse grave problema, reunida em concílio, buscou resolver esse grave desafio em face da existência de corrupção e irregularidades várias. Essa medida legislativa teve que ser enérgica, declarando nula e de nenhum efeito a eleição de bispo, caso realizada pelos governantes ${ }^{103}$. Além disso, aqui vale recordar que a vedação se estendia também a presbíteros e diáconos.

No século IX, houve o Concílio Ecumênico de Constantinopla (IV) entre os anos de (869-870). Esse também faz alusão à escolha dos bispos. Só poderiam ser eleitos pelo Colégio Episcopal, excluindo assim as autoridades civis: «Apostolicis et synodicis canonibus, promotiones et consecrationes episcoporum et potentia et praeceptione

\footnotetext{
101 Concilium Oecumenicum NicAenum Ii, can. 3, in (G. Alberigo et Alit, curr.), Conciliorum, 140.

102 Cf. J. I. Gonsález FAUS, Nenhum, 66.

103 Cf. M. TKhorovskyY, Procedura, 18.
} 
principum factas penitus interdicentibus, concordantes definimus et sentenciam nos quoque proferimus» ${ }^{104}$.

Assim sendo, o cânon 12 estabelece que as eleições feitas pela influência do poder político não eram reconhecidas. Esse cânon restabeleceu a autoridade eclesial na eleição episcopal, valorizando o Colégio Episcopal, responsável para essa tarefa por meio de decreto. Além disso, aborda que nenhum dos príncipes ou autoridades seculares ou civis, deveria se intrometer nas eleições episcopais de qualquer bispo, patriarca e metropolita. Essas autoridades ou leigos estavam proibidas de exercer poder ou influência sobre os eclesiásticos.

Esses dois concílios, Nicéia II e Constantinopla IV, em razão de sua rigidez normativa, provocaram graves problemas internos, pois, a exclusão dos poderes civis na escolha dos bispos, dada a usurpação do poder clerical na maior parte das regiões, estendeu também a proibição participativa aos leigos em geral. É fato que ocorreu muitos abusos por parte de poderes temporais, por isso acha-se necessário fazer uma dicotomia entre os poderes "laicos" e leigos. Acredita-se que a intenção desses concílios era a recuperação do binômio "clero e povo" 105 .

Em linhas gerais, nesses últimos séculos, a Igreja buscava liberdade para a nomeação de bispo, mas os reis tinham muita força e não abriam mão de fazer a escolha. Certamente, o que foi tratado nesses últimos séculos, pode-se dizer que foi onde a Igreja teve maior abertura e liberdade, uma vez que muitos monarcas respeitavam as revindicações feitas pela Igreja. Entretanto, nesse período começou ocorrer uma feudalização do episcopado ${ }^{106}$, na qual se verifica mais intromissão dos poderes civis.

Os reis desempenharam um papel de proteção da Igreja e foi, a partir dessa dimensão de proteção, que começaram a ter maior ingerência nas escolhas episcopais. Primeiramente, tinha-se, de um lado, a aprovação do candidato por parte do monarca, com uma certa semelhança com a função de aprovação do metropolita. Por outro lado,

\footnotetext{
104 Concilium Oecumenicum Constantinopolitanum IV, can. 12, in (G. AlbeRIGO ET ALII, curr.), Conciliorum, 175.

105 Cf. J. I. GonsÁlez FAUs, Nenhum, 69.

${ }^{106}$ Cf. J. I. GonsÁlez Faus, Nenhum, 84.
} 
com o passar do tempo, o rei vai substituir os eleitores, uma vez que ele mesmo escolhia o bispo. Entretanto, devemos dizer que essa práxis não era uniforme, porque dependia muito de rei para rei.

Certamente, havia alguns que ostentavam muita pretensão com a nomeação episcopal, como o rei Carlos Magno quando se tornou imperador no ano 800. Ele mesmo queria nomear bispos, clérigos e convocar concílios, embora reconhecesse o supremo magistério do romano pontífice em matéria disciplinar e doutrinária ${ }^{107}$. Porém, outros reis respeitavam as decisões de concílios e as revindicações que a Igreja fazia por meio do papa ou de outras autoridades eclesiásticas. Deste modo, as designações episcopais ficavam na dependência do comportamento de cada monarca, uns mais intrometidos, não abrindo mão de seu poder de escolha; outros não se preocupavam tanto com as escolhas episcopais.

Nos séculos IX e X, a Igreja se esforçou para retornar ao princípio eletivo pelo clero e povo, pois esses eram os verdadeiros eleitores que se manifestavam como a maioria que seria liderada pelo novo bispo $^{108}$. Nesse final do primeiro milênio, o poder civil, em especial os reis, exerciam poder supremo no governo ${ }^{109}$, numa época em que «manifestava um desprezo por demais evidente da antiga exigência canônica de engajar ativamente o clero e os leigos na nomeação dos bispos por meio de eleição livre e canônica» ${ }^{110}$. Essa antiga normativa canônica que possibilitava ao clero e aos leigos a nomeação dos bispos, parecia não ser mais a preocupação por parte dos papas, pois o retorno ao chamado princípio eletivo foi sendo deixado de lado, diante dos papas que queriam reservar para si as nomeações episcopais ${ }^{111}$.

\section{Conclusão}

As escolhas episcopais na história da Igreja é um tema empolgante e apaixonante. Durante o primeiro milênio, é possível encontrar

\footnotetext{
${ }^{107}$ Cf. G. L. FALCHI - B. E. FeRME, Introduzione, 139.

108 Cf. W. Ullmann, Os Reis, 919.

109 Cf.W. Ullmann, Os Reis, 919.

110 W. UllmanN, Os Reis, 920.

111 Cf. J. I. GonsÁLEZ FAUS, Nenhum, 96.
} 
inúmeras fontes que abordam as diversas formas e sistemas das escolhas episcopais. Entre a fonte primária (Sagrada Escritura - Novo Testamento) e os diversos textos normativos, aqui incluídos os muitos concílios realizados pela Igreja, a escolha do pastor sempre foi alvo de grande preocupação inclusive dos poderes civis, daí porque a história tem sido alvo de estudo e escritores, seja na patrologia, seja de outra natureza. História de tensões, conflitos e de muita instabilidade que rodeou a escolha dos candidatos ao episcopado.

Tivemos como primeira preocupação analisar e verificar nos textos bíblicos, especialmente no Novo Testamento, o espírito e o objetivo pelos quais Jesus Cristo escolheu os apóstolos. Ficou muito evidente que os apóstolos deveriam continuar anunciando o Reino dos Céus, como escolhidos do Filho de Deus. Em seguida, esses mesmos apóstolos tiveram a incumbência de designar aqueles que ficariam à frente de comunidades cristãs e desempenhando funções especificas de liderança dentro dos grupos dessas comunidades.

De um lado, no Oriente, a escolha episcopal costumava ocorrer na presença do metropolita que possuía uma função de juiz, sopesando as qualidades do candidato. Por outro lado, já no Ocidente, em outro contexto histórico, a escolha dos bispos, em um primeiro momento, dava-se forte participação do clero, do povo e dos bispos vizinhos da diocese vacante. Naqueles primeiros séculos, havia a preocupação de envolver os membros da Igreja local, mas com o passar do tempo, isso iria mudar. Nesse contexto eclesial, havia aquilo que foi chamado de princípio eletivo que passava pelos superiores, bem como pelos inferiores dentro do ordenamento organizacional primitivo das comunidades cristãs.

Depois do século quarto, as nomeações episcopais despertaram muito interesse do poder temporal, ficando bem evidente e claro ao final do primeiro milênio. Primeiramente por parte dos imperadores, reis, príncipes e outros tipos de soberanos que, por meio do poder ou de acordos com a Igreja, puderam fazer inúmeras nomeações episcopais. Por outro lado, papas e bispos lutaram contra os abusos e as investidas do poder civil no confronto das matérias eclesiásticas, uma vez que prejudicavam a Igreja dada a supremacia dos interesses mundanos sobre os espirituais. 


\section{Bibliografia}

\section{Fontes}

BíBliA, A Bíblia de Jerusalém, ed. portuguesa, São Paulo, 1973.

CONCILIUM BRAGAENSE (572), in (J. VIVES, cur.), Concilios visigoticos e hispano-romanos, Barcelona-Madrid, I, 1963, 78-106.

Concilium Toletanum IV (633), in (J. VIVES, cur.), Concilios visigoticos e hispano-romanos, Barcelona-Madrid, I, 1963, 186-225.

Concilium Toletanum XII (681), in (J. Vives, cur.), Concilios visigoticos e hispano-romanos, Barcelona-Madrid, I, 1963, 380410.

Concilium Oecumenicum Nicaenum II, in (G. Alberigo et alit, curr.), Conciliorum Oecumenicorum Decreta, Bologna, 1996.

Concilium Oecumenicum Constantinopolitanum IV, in (G. AlBerigo et ALII, curr.), Conciliorum Oecumenicorum Decreta, Bologna, 1996.

\section{Padres}

ORIGENES, In Leviticum Homilia VI, 3, in (J.-P. Migne, cur.), Patrologiae cursus completus. Series Graeca, XII, Paris, 1862.

Celestinus I, Epistola ad Episcopos Viennenses, caput. 5, in (J.-P. Migne, cur.), Patrologiae cursus completus. Series Latina, L, Paris, 1865.

Clemens, Ad Corinthios Epistula LVIII, in (G. Morin, cur.), Sancti Clementis Romani ad Corinthios Epistulae versio latina antiquissima, Maredsoli, 1894.

Cyprianus, Epistolae 67,5, in (M. J. ROUËT DE JOURnel, cur.), Enchiridion Patristicum, n. 588, Paris, 1946.

Cyprianus, Epistolae 55, 8, in (M. J. ROUËT DE JOURnel, cur.), Enchiridion Patristicum, n. 575, Paris, 1946. 
Ambrosius, Epistolae XI, caput XI, in (J.-P. Migne, cur.), Patrologiae cursus completus. Series Latina, XXI, Paris, 1865.

DIDAQuÉ, O Catecismo dos primeiros Cristãos para as comunidades de hoje, São Paulo, 1989.

Possidius, Vita Santi Augustini, caput. 21, in (J.-P. Migne, cur.), Patrologiae cursus completus. Series Latina, XXXII, Paris, 1877.

Leo Magnus, Epistolae XIV, ad Episcopum Iliria, caput 3, in (J.-P. Migne, cur.), Patrologiae cursus completus. Series Latina, LIV, Paris, 1881.

Leo Magnus, Epistolae X, ad Episcopum Viennae, caput 6, in (J.-P. Migne, cur.), Patrologiae cursus completus. Series Latina, LIV, Paris, 1881.

\section{Autores}

AlBerigo G., A Igreja na História, São Paulo, 1999.

Congar Y. M. J., Os leigos na Igreja. Escalões para uma teologia do laicato, São Paulo, 1966.

Eugui J., La participación de la comunidad Cristiana en la elección de los Obispos, Pamplona, 1977.

FAIVRe A., Os leigos na origem da Igreja, Petrópolis, 1992.

FAlCHI G. L. - FERME B. E., Introduzione allo Studio delle fonti dell "Utrumque ius", Coll. Studia et Documenta, Sectio Iuris Romani et Historiae Iuris, n. 7, Città del Vaticano, 2006.

Gaudemet J., Storia del Diritto Canonico, Torino, 1998.

Ghirlanda G., O direito na Igreja: mistério de comunhão, Aparecida, 2003.

GonZÁlez Faus J. I., Nenhum bispo imposto: as eleições Episcopais na história da Igreja, São Paulo, 1996.

KeLty E. J., The qualities requested of episcopal candidates in the early Church and in the middle ages, Roma, 2006. 
KNOWLes D., Nova história da Igreja II, Petrópolis, 1974.

Melloni A., Como se elege um papa: a história do conclave, São Paulo, 2002.

NAz R., Introduction Règles Générales des Personnes, Paris, 1954.

PlöChl W. M., Storia del Diritto Canonico. Dalle origini della Chiesa allo scisma d'Oriente (1054), I, Milano, 1963.

SchAtz K., Elección de Obispos. Historia y teología, Barcelona, 1991.

\section{ARtigos}

BARTElink G., "Eleição” e “Consensus” na linguagem Cristã (até o cerca do ano 600), in Concilium (1972 ), n. 77, 973-980.

CARON P. G., L'intervention de l'autorité impériale romaine dans l'éléction des évêques, in Revue de droit canonique, XXVIII (1978), n. 2-4, 76-83.

G. CORBELLINI, Le modalità per la scelta dei candidati all Episcopato nel Codice di Diritto Canonico con particolare riferimento alle proposte avanzate per la redazione dei nuovi canoni, in (D. J., ANDRÉs GUTIÉRREZ, cur.), II processo di designazione dei Vescovi. Storia, legislazione, prassi. Symposium CanonisticoRomanistico, Città del Vaticano, 1996, 323-383.

De Rome H., De Episcopi, in (B. BotTe, cur.), Hippolyte de Roma. La tradition apostolique d'après les anciennes versions, Paris, 1968, 40-43.

Eugui J., La partecipazione della Comunità Cristiana all'elezione dei Vescovi tra il I e il V Secolo, in (D. J., ANDRÉS GUTIÉRREZ, cur.), Il processo di designazione dei Vescovi. Storia, legislazione, prassi. Atti del X Symposium Canonistico-Romanistico, Coll. Utrumque ius, 27, Città del Vaticano, 1996, 49-66. 
Floristán C., A escolha dos bispos, in AA.Vv., Bispos para esperança do mundo: uma leitura crítica sobre caminhos de Igreja, São Paulo, 2000, 257-271.

GANSHOF F. L., Note sur l'éléction des évêques dans l'Empire romain au IV et pendani la première moitié du V siècle, in Mélanges Fernand de Vischer, Revue international des Droits de l'Antiquité, IV (1950), 467-498.

GAUDEMET J., A escolha dos bispos: uma história atormentada, in Concilium (1996), n. 267, 79-86.

Huizing P. - WAlf K., Editorial, in Concilium (1980), n. 157, 3-5.

KöLMEL W., As eleições episcopais e os poderes políticos: em que medida as eleições episcopais deram ensejo a manipulações por parte dos poderes politicos, in Concilium (1972), n. 77, 908916.

KotTJE R., A escolha das autoridades eclesiásticas: fatos históricos e experiências, in Concilium (1971), n. 63, 346-354.

LEGRAND H. M., O sentido teológico das eleições episcopais segundo seu desenrolar na Igreja antiga, in Concilium (1972), n. 77, 876-885.

Provost J. H. - Walf K., Estruturas centrais da Igreja, in Concilium (1979), n. 147, 3-12.

Provost J. H. - Walf K., A escolha dos bispos, in Concilium (1988), n. 220, 3-5.

REMY J., Colaboração do povo de Deus na escolha e na designação dos bispos, in Concilium (1980), n. 157, 81-89.

SCHNACKenburg R., Participação da comunidade por consenso $e$ eleição no Novo Testamento, in Concilium (1972), n. 77, 856865.

StockmeIER P., A eleição do bispo pelo clero e pelo povo na Igreja primitiva, in Concilium (1980), n. 157, 6-14. 
TKHOROVSKYY M., Procedura per la nomina dei Vescovi: evoluzione dal Codice del 1917 al Codice del 1983, Roma, 2004.

Ullmann W., Os Reis da França e a eleição dos bispos nos séculos IX e X, in Concilium (1972), n. 77, 917-922.

Wiedenhofer S., Eclesiologia, in AA.Vv., Manual de Dogmática, Petrópolis, 2001, 50-142. 